\title{
Ordu ilinde yumurta tüketim bilincinin belirlenmesi
}

\section{Sezai ALKAN ${ }^{1}$, Sibel DEREBAȘI ${ }^{1}$}

10rdu Üniversitesi Ziraat Fakültesi Zootekni Bölümü, ORDU

Alınış tarihi: 18 Temmuz 2018, Kabul tarihi: 15 Ekim 2018

Sorumlu yazar: Sezai ALKAN, e-posta: sezaialkan61@gmail.com

\section{Öz}

Bu çalışmada Ordu ilinde yaşayan insanların yumurta tüketim bilincinin belirlenmesi amaçlanmıștır. Çalışmada 2017 yılında Ordu ilinde ikamet eden vatandaşlardan basit tesadüfi örnekleme yoluyla belirlenen 387 kişi ile yüz yüze yapılan anketlerden elde edilen veriler kullanılmıştır. Araştırma sonuçlarına göre, hane genişliği 3.33 kişi, hane başına haftallk yumurta tüketimi ortalama 18,68 adet olarak bulunmuștur. Hanelerin ortalama ayllk geliri 4296.50 TL olup ortalama ayllk gida harcaması ise 968.60 TL olarak tespit edilmiştir. Araştırmada, tüketicilerin $\% 90,44^{\prime}$ ü organik yumurta hakkında bilgi sahibi olduğunu belirtmiştir. Tüketicilerin $\% 76,23$ 'ünün yumurtanın üzerindeki harflerin $(\mathrm{S}, \mathrm{M}$, L, XL) ne anlama geldiğini bildiği saptanmıştır. Tüketicilerin \%79.33'ü yumurta fiyatındaki artış ya da azalmanın tüketim miktarını etkilemediğini bildirmiştir. Tüketicilerin \%61.76'sı yumurtanın sağlıklı koşullarda üretildiğine inandığını ifade etmiştir. Aynı zamanda, tüketicilerin \%50,9'u kirli yumurtanın bir pazarlama stratejisi olduğunu belirtmiştir. Tüketicilerin \%16.8'i yumurtanın kan kolesterolünü arttırdığını belirtmiştir.

Anahtar kelimeler: Yumurta, tüketim bilinci, Ordu ili, anket

\section{Determination of egg consumption consciousness in Ordu province}

\footnotetext{
Abstract

In this study, it was aimed to determine the egg consumption consciousness of the people living in Ordu province. In the study, the data were collected by face-to-face surveyings with 387 people determined by simple random sampling from citizens residing in
}

Ordu province in 2017. Based on the surveys, the household size was found to be 3.33 persons, and the average weekly consumption of eggs per household was 18,68. The average monthly income of the household is found to be $4296.50 \mathrm{TL}$ and the average monthly food expenditures were determined as 968.60 TL. In the study, $90.44 \%$ of consumers stated that they have knowledge about organic eggs. It has been determined that $76.23 \%$ of the consumers know the meaning of letters (S, M, L, XL) found on the eggs. Moreover, $79.33 \%$ of the consumers reported that the increase or decrease in egg price did not affect the amount of eggs that they consume. It was also found that $61.76 \%$ of consumers believed that eggs were produced under healthy conditions. At the same time, $50.9 \%$ of consumers said that it was a marketing strategy for a dirty egg. $16.8 \%$ of the consumers stated that eggs increased blood cholesterol.

Key words: Egg, consumption consciousness, Ordu province, survey

\section{Giriş}

Ülkelerin sağlıklı yaşaması ve ekonomik yönden gelişmesi, onu oluşturan bireylerin sağlıklı olmasına bağlıdır. İnsan sağlığının temeli ise yeterli ve dengeli beslenmeye dayanmaktadır. Sağlıklı ve dengeli beslenme için ihtiyaç duyulan enerji, protein, vitamin ve mineraller, hayvansal ve bitkisel gıda kaynaklarından sağlanmaktadır. Et, süt, yumurta gibi hayvansal gıda kaynakları, bitkisel gıda kaynaklarına göre ilgili besin maddelerini daha bol, dengeli ve daha fazla yararlanabilir şekilde içermelerinden dolayı beslenmede ilk sırayı almaktadırlar. Ayrıca hayvansal gida kaynakları çocukluk ve gençlik evrelerinde büyüme ve gelişim evrelerinde, yaşlılık dönemlerinde ise orga- 
nizmanın düzgün çalışması için oldukça önemlidir (Özkan, 1986).

Dünyanın her tarafında önemli bir hayvansal gıda kaynağı olan yumurta, geçmişten günümüze insan beslenmesinde kıymetli bir hayvansal protein kaynağı olarak yerini korumaktadır ve aynı şekilde gelecekte de bu özelliğini koruması kaçınılmaz görünmektedir (Uluocak ve ark. 1996; Hasipek ve Aktaş, 1997).

Yumurta doğal yapısı itibari ile hile karıștırılamayan "korunmuş" bir gida maddesidir. Yumurta, yeterli ve dengeli beslenme için gereksinim duyulan tüm esansiyel besin maddelerini içeren bir gıdadır. Hayvansal ürünler içerisinde en iyi protein kalitesine sahip olan yumurta A, D, E, K ve B grubu vitaminlerin yanı sıra demir ve fosfor gibi mineral maddelerce de zengindir (Stadelman ve ark,, 1988). Bunun yanında kolay sindirilebilmesi ve düşük kalori değerine (80 kkal) sahip olması nedeniyle yaşlıların, hastaların ve diyetteki insanların beslenmesinde önemli bir yer tutmaktadır. Yumurta proteininin esansiyel aminoasitlerce zengin olmasından dolayı biyolojik değeri 100 olarak kabul edilmektedir. Buna bağlı olarak diğer gida maddelerinin kalitesinin saptanmasinda yumurtanın bu özelliği standart olarak kullanılmaktadır (Altan, 2015; Türkoğlu ve Sarıca, 2014). Yumurtanın ucuz bir protein kaynağı olması, kolay ulaşılabilir olması ve kolay hazırlanması tercih edilme sebeplerindendir. 2016 yılında kişi başı yıllık yumurta tüketimi, Japonya'da 331 adet, Rusya'da 295 adet, Çin'de 282 adet, Arjantin'de 273, ABD'de 272 adet ve Almanya'da 235 adet olmuştur. Türkiye'de ise 1997 yılında 113 adet/yıl olan kişi başı tüketilen yumurta sayısı, 2017 yılında 214 adet/yıla çıkmıştır (Anonim, 2017).

Çalışmanın uygulandığı il olan Ordu'da 19 ticari işletmede yaklaşık 247 bin yumurta tavuğu kapasitesi bulunmaktadır (Anonim, 2017). Son zamanlarda uygulanan serbest sistem yumurta tavukçuluğu projesiyle serbest sistemde üretilen yumurta miktarı giderek artmaktadır. Ancak yumurta tüketimi ile ilgili artış veya azalış eğilimi konusunda yeterli bilgi bulunmamaktadır. İnsan beslenmesinde önemli bir yeri olan yumurtanın tüketicilerin satın alma davranışlarının ve bilinç düzeylerinin bilinmesi, yetiştirme ve besleme modellerinin belirlenmesi, stratejiler geliştirilmesi açısından çok önemlidir.

Ordu ilinin de içinde yer aldığg Karadeniz bölgesini oluşturan illerde benzer bir çalışma yapılma- mış olması çalışmanın özgünlüğü bakımından önemlidir. Yumurta ile ilgili yanlış bilinen doğrular veya doğru bilinen yanlışların ortaya konulmasına yönelik daha çok çalışmaya ve sonuçlarının çeşitli iletişim araçları ile tüketicilere ulaştırılmasına ihtiyaç vardır.

Çalışmanın sonuçlarının, bölgesel kalkınma çerçevesinde tüketici eğilimine yönelik pazarlama stratejilerinin geliştirilebilmesine, toplumsal bilincin artırılmasına yönelik eğitim çalışmalarının planlanmasına yardımcı olacağı düşünülmektedir. Bu çalışmada, Ordu ili kent merkezinde yaşayan tüketicilerin yumurta tüketim bilinçlerinin ortaya konulması amaçlanmıştır.

\section{Materyal ve Yöntem}

\section{Materyal}

$\mathrm{Bu}$ çalışmada veri toplama yöntemi olarak yüz yüze görüşme, veri toplama aracı olarak ise araştırma değişkenlerini ölçmeye yönelik olarak hazırlanmış anket formları kullanılmıştır. Anket formları demografik soruların yanı sıra katılımcıların tüketim bilincini belirlemek amacıyla hazırlanmış olan sorulardan oluşturulmuştur. Türk Gıda Kodeksi yumurta Tebliği'ne (Resmi Gazete 2014, sayı 29211) göre yumurta özellikleri bakımından A ve B sınıfı olmak üzere iki sınıfa ayrılmaktadır. B sinıfi yumurtalar gida sanayinde kullanılmaktadır. Tüm dünyada kullanılan ve Türkiye'de yumurta tebliğinde yer alan A sınıfı yumurtaların ağırlığına göre sınıflandırıldığı bir harf sistemi vardır. Bu sisteme göre, XL (çok büyük), L (büyük), M (orta), S (küçük) ağırlık sınıfını ifade etmektedir.

\section{Yöntem}

\section{Çalışma evreni ve örneklem}

Çalışmanın evrenini 2017 yılında Ordu ilinde ikamet eden vatandaşlar oluşturmuştur. Çalışmanın örneklemini aşağıdaki formülden yararlanarak basit tesadüfi örnekleme yoluyla belirlenen toplam 387 kişi oluşturmuştur (Akbay ve ark. 2007).

$\mathrm{n}=\left(\mathrm{t}^{2 *} \mathrm{p} \mathrm{q}\right) / \mathrm{E}^{2}$

$\mathrm{n}$ : örnek hacmi

$\mathrm{t}^{2}=$ Güven katsayısı (\%95'lik güven için bu katsayı 1.96 alınmıştır)

$\mathrm{p}=$ Populasyona ait oran değeri $(0.50)$

$\mathrm{q}=1-\mathrm{P}=0,50$

$\mathrm{e}=$ Kabul edilen örnekleme hata payı (\%5) 


\section{İstatistik değerlendirme}

Ankete katılanların formlarda yer alan sorulara verdikleri cevapların frekans analizi yapılarak hem frekans değerleri (n) hem de \% frekans değerleri hesaplanmıştır. Tüm hesaplamalar SPSS v24 (IBM Inc,, Chicago, IL, USA) istatistik paket programı kullanılarak yapılmıştır.

\section{Bulgular ve Tartışma}

\section{Katılımcıların bireysel ve hanelerine ilișkin özellikler}

Araştırma alanı olan Ordu ilinde yürütülen anket çalışmasında katılımcıların bireysel özellikleri ile ailelerin demografik özelliklerinin belirlenmesi için sorulan sorulara verilen cevaplardan elde edilen frekans değerleri (n ve \% olarak) Çizelge 1' de verilmiştir. Anketi cevaplandıran tüketicilerin $\%$ 64.34'ü erkek, \% 35.66' sı ise kadındır. Anket yapılan hanelerdeki toplam nüfus 1287 kişi olup genel olarak aileler 4 kişilik ( \% 30.75) ve 3 kișilik (\% 29.46) ailelerden olușmuștur. Araștırma alanının hane genişliği 3,33 bulunmuștur. Araștırmaya katılan tüketicilerin ve eşlerinin ücretli bir işte çalışma durumu incelendiğinde, ankete katılanların \% 74.42'si, eşlerin ise \% 37.21'i bir işte çalışmaktadır. Çalışma durumu ile ilgili soruyu cevaplandırmayanların oranı ise \% 9.82 bulunmuştur. Araştırmaya katılan katılımcıların \% 20.16'sı ilköğretim ( ilkokul, ortaokul) mezunu iken, \% 28.17' si lise mezunu, \% 44.19'u üniversite ve üzeri (ön lisans, lisans ve lisansüstü) mezunu olduklarını ifade etmişlerdir. Katılımcıların $\% 7.49$ 'u ise eğitim durumunu cevaplandırmak istememiștir. Bununla birlikte ankete katılan tüketicilerin eşlerinin yaklaşık \%32,30 'u üniversite mezunu olup bunu sirasıyla ilköğretim (\% 24) ve lise (\%21) mezunu izlemiștir. Yine eğitim durumunu söylemek istemeyenlerin oranı yaklaşık \% 21.7 olarak bulunmuştur. Ankete katılan tüketicilere açık uçlu olarak mesleği sorulmuș olup alınan cevaplar 6 meslek grubunda toplanmıştır. Buna göre ankete katılanların \% 31.01'i memur, \% $14.99^{\prime}$ u mühendis, \% 13.95'i işçi, \% 23.26' sı serbest meslek, \% 9.3' ü ev hanımı ve \% 7.49'u emeklidir. Ankete katılan kișilerin yaș ortalaması 41.77 yıl, eşlerinin yaş ortalaması ise 41.85 yıl olarak tespit edilmiștir. Anket uygulanan hanelerin toplam aylık geliri $4296.56 \mathrm{TL}$, ortalama aylık gıda harcaması ise 968.59 TL olarak belirlenirken hane başına tüketilen ortalama yumurta sayısı 18.68 adet/hafta ( 74.72 adet/ay) olarak bulunmuştur ( Çizelge 2). Çalışmada elde edilen 74.72 adet/hane/ay (271,7 adet /kiși/ yll) yumurta tüketim miktarı Yurdakul ve Akdemir (1989)'in bulduğu 234.3 adet /kişi/yıl miktarına yakındır. Buna karşın, Akdemir (1989)'in bildirdiği 154 adet/hane/ay tüketiminden oldukça az, Durmuş ve ark., (2007)'nın bildirdiği 171 adet /kişi/ yıl, Çelik ve Şengül (2001)'in bildirdiği 126 adet /kişi/ yll ve Erdoğan (2013)'ün bildirdiği 129 adet /kişi/yıl tüketimden oldukça fazladır. Sonuçların farklı olmasında hane genişliğinin ve anket uygulanan çalışma alanının farklı olmasının etkisinin bulunduğu düşünülmektedir.

\section{Katılımcıların yumurta tüketim bilincine iliş- kin temel bulgular}

Araştırma alanı olan Ordu ili ve 19 ilçesinde yürütülen anket çalışmasında katılımcıların ve ailelerinin yumurta tüketim bilinç düzeyinin belirlenmesine ilişkin sorular ve verilen cevaplardan elde edilen frekans değerleri (n ve \% olarak) Çizelge 3'te verilmiștir. Yumurta etiketlerinde yer alan S, M, L, XL gibi harflerin ne anlama geldiğini belirlemek için sorulan soruya tüketicilerin \% 76.23'ü evet, \% 23.77'si ise hayır cevabını vermiştir (Çizelge 3). Tüketicilerin bu konudaki bilinç düzeyinin oldukça yüksek olduğu görülmüştür. Organik yumurtanın ne olduğunun ortaya konulması amaclyla sorulan soruya tüketicilerin $\% 90.44$ 'ü organik yumurtanın ne olduğunu bildiklerini belirtmiştir. Ancak tüketicilere sözlü olarak organik yumurtanın ne olduğu sorulduğunda, çoğunluğunun kafeste üretilmeyen ya da köy şartlarında yetiştirilen yumurta olarak algıladıkları görülmüştür. Buna karşın, tüketicilerin organik yumurta üretiminin bir sertifikasının olması gerektiğini ve organik tarım kurallarıyla üretilmesinin zorunlu olduğunu bilmedikleri belirlenmiştir. Mızrak ve ark., (2012) tarafından Türkiye genelinde yapılan bir anket çalışmasında ankete katılanların \%72.4'ünün ve Durmuş ve ark., (2007) yapılan çalışmada ise ankete katılanların \% 87.2'sinin organik yumurta hakkında bilgi sahibi olmadıkları belirtilmiștir. Buna karşın, İskender ve ark. (2014) tarafından yapılan başka bir çalışmada ise ankete katılanların \% 81.2'sinin organik yumurtayı bildikleri belirlenmiştir.

Yumurta fiyatlarında meydana gelen dalgalanmaların tüketim miktarını etkileyip etkilemediğini araştırmak için sorulan soruya tüketicilerin \% 19.90'u etkilendiğini, buna karşın \% 79.33'ü etkilenmediğini bildirmişlerdir. 
Çizelge 1. Katılımcıların bireysel özellikleri ile ailelerin demografik özellikleri

\begin{tabular}{|c|c|c|c|c|}
\hline \multirow{2}{*}{ No } & \multirow{2}{*}{ Değişkenler } & & \multicolumn{2}{|c|}{ Frekans } \\
\hline & & & $\mathrm{n}$ & $\%$ \\
\hline \multirow{7}{*}{1} & \multirow{7}{*}{ Mesleğiniz? } & Memur & 120 & 31.01 \\
\hline & & Mühendis & 58 & 14.99 \\
\hline & & İşçi & 54 & 13.95 \\
\hline & & Serbest Meslek & 90 & 23.26 \\
\hline & & Ev Hanımı & 36 & 9.3 \\
\hline & & Emekli & 29 & 7.49 \\
\hline & & Toplam & 387 & 100 \\
\hline \multirow{5}{*}{2} & \multirow{5}{*}{ Katılımcının Eğitim Durumu } & İlkokul-Ortaokul & 78 & 20.16 \\
\hline & & Lise & 109 & 28.17 \\
\hline & & Üniversite ve Üstü & 171 & 44.19 \\
\hline & & Cevap Vermeyen & 29 & 7.49 \\
\hline & & Toplam & 387 & 100 \\
\hline \multirow{5}{*}{3} & \multirow{5}{*}{$\begin{array}{l}\text { Anket Sorularını Cevaplandıran Katılımcı- } \\
\text { nın Eşinin Eğitim Durumu }\end{array}$} & Lise altı & 95 & 24.55 \\
\hline & & Lise & 83 & 21.45 \\
\hline & & Üniversite ve Üstü & 125 & 32.30 \\
\hline & & Cevap Vermeyen & 84 & 21.70 \\
\hline & & Toplam & 387 & 100 \\
\hline \multirow{4}{*}{4} & \multirow{4}{*}{ Katılımcının Çalışma Durumu } & Çalışıyor & 288 & 74.42 \\
\hline & & Çalışmıyor & 61 & 15.76 \\
\hline & & Cevap Vermeyenler & 38 & 9.82 \\
\hline & & Toplam & 387 & 100 \\
\hline \multirow{4}{*}{5} & \multirow{4}{*}{ Katılımcının Eşinin Çalışma Durumu } & Çalışıyor & 144 & 37.21 \\
\hline & & Çalışmıyor & 132 & 34.11 \\
\hline & & Cevap Vermeyenler & 111 & 28.17 \\
\hline & & Toplam & 387 & 100 \\
\hline \multirow{3}{*}{7} & \multirow{3}{*}{ Ankete katılanların cinsiyeti } & Erkek & 249 & 64.3 \\
\hline & & Kadın & 138 & 35.6 \\
\hline & & Toplam & 387 & 100 \\
\hline \multirow{8}{*}{8} & \multirow{8}{*}{$\begin{array}{l}\text { Hanede yaşayan kiși sayısı } \\
\text { (Hane halkı genișliği) }\end{array}$} & 1 kişi & 30 & 7.75 \\
\hline & & 2 kişi & 65 & 16.8 \\
\hline & & 3 kişi & 114 & 29.46 \\
\hline & & 4 kiși & 119 & 30.75 \\
\hline & & 5 kişi & 48 & 12.4 \\
\hline & & 6 kişi & 8 & 2.07 \\
\hline & & 7 ve + kişi & 3 & 0.78 \\
\hline & & Toplam & 387 & 100.00 \\
\hline
\end{tabular}

Çizelge 2. Ankete katılanların yaş, gelir, harcama ve haftalık yumurta tüketimlerine ait tanıtıcı değerler

\begin{tabular}{|c|c|c|c|c|c|c|}
\hline Değişken & $\mathrm{n}$ & Ortalama & Ortanca & Std. Sapma & Minimum & Maksimum \\
\hline Katılımcının yaşı (yıl) & 366 & 41.77 & 40.00 & 11.48 & 18.00 & 78.00 \\
\hline Eşinin yaşı (yıl) & 310 & 41.85 & 40.00 & 10.83 & 24.00 & 80.00 \\
\hline Toplam hane geliri (TL) & 387 & 4296.56 & 4000.00 & 2304.67 & 800.00 & 15000.00 \\
\hline Hanenin aylık gıda harcamaları miktarı (TL) & 382 & 968.59 & 800.00 & 518.52 & 100.00 & 3000.00 \\
\hline $\begin{array}{l}\text { Hanede haftada tüketilen yumurta miktarı } \\
\text { (adet) }\end{array}$ & 386 & 18.68 & 15.00 & 10.75 & 1.00 & 60.00 \\
\hline
\end{tabular}


Bu sonuç, konu ile ilgili yapılan birçok çalışmada belirtilen fiyatın, tüketim ve satın alma kararlarını etkileyen en önemli faktör olduğu sonuçlarıyla uyumlu değildir (Özçiçek, 2003; Goddard ve ark. 2007; Fearne ve Laverne, 1987; Mesias ve ark. 2011). Bu çelişkinin en önemli nedeni olarak Türk toplumunun mutfağında gelenekselleşmiş gıda maddelerinden olan ekmek gibi yumurtanın da fiyatı ne olursa olsun mutlaka sofrada yerini al- ması gereken bir ürün olarak görülmesinden kaynaklanmış olabileceği düşünülmektedir. Özellikle anneler çocuklarını kahvaltıda yumurta tüketmeden okula göndermeme davranışına sahiptirler. $\mathrm{Bu}$ durumun araştırma alanında yumurta tüketim bilincinin yanında tüketim alışkanlığı ile de ilgili olduğu düşünülmektedir. Bu nedenle fiyat artışı ya da azalışları tüketici davranışını önemli derecede etkilememiştir.

Çizelge 3. Katılımcıların yumurta tüketim bilincine ilişkin tanıtıcı değerler

\begin{tabular}{|c|c|c|c|c|}
\hline \multirow{2}{*}{ No } & \multirow{2}{*}{ Değişkenler } & & \multicolumn{2}{|c|}{ Frekans } \\
\hline & & & $\mathrm{n}$ & $\%$ \\
\hline \multirow{4}{*}{1} & \multirow{4}{*}{ Organik yumurtanın bilinirliği durumu } & Evet & 350 & 90.44 \\
\hline & & Hayır & 31 & 8.01 \\
\hline & & Cevap vermeyenler & 6 & 1.55 \\
\hline & & Toplam & 387 & 100 \\
\hline \multirow{3}{*}{2} & \multirow{3}{*}{$\begin{array}{l}\text { Etiketlerdeki yumurta ağırlıklarına göre sınıf- } \\
\text { landırmanın bilinirliği durumu }\end{array}$} & Evet & 295 & 76.23 \\
\hline & & Hayır & 92 & 23.77 \\
\hline & & Toplam & 387 & 100 \\
\hline \multirow{4}{*}{3} & \multirow{4}{*}{$\begin{array}{l}\text { Yumurta tüketiminin fiyatlardan etkilenme } \\
\text { durumu }\end{array}$} & Evet & 77 & 19.9 \\
\hline & & Hayır & 307 & 79.33 \\
\hline & & Cevap vermeyenler & 3 & 0.78 \\
\hline & & Toplam & 387 & 100 \\
\hline \multirow{4}{*}{4} & \multirow{4}{*}{$\begin{array}{c}\text { TV programlarında yer alan yumurta-kolesterol } \\
\text { tartışmalarının yumurta tüketimini etkileme } \\
\text { durumu }\end{array}$} & Etkilemedi & 344 & 88.88 \\
\hline & & Arttı & 20 & 5.17 \\
\hline & & Azaldı & 23 & 5.95 \\
\hline & & Toplam & 387 & 100 \\
\hline \multirow{4}{*}{5} & \multirow{4}{*}{$\begin{array}{l}\text { Yumurta üreten ya da yumurta satışı yapan } \\
\text { işlemelerinin denetimleri hakkında bilgi düzeyi }\end{array}$} & Evet & 159 & 41.08 \\
\hline & & Hayır & 220 & 56.84 \\
\hline & & Fikrim yok & 8 & 2.08 \\
\hline & & Toplam & 387 & 100 \\
\hline \multirow{5}{*}{6} & \multirow{5}{*}{$\begin{array}{l}\text { Satın alınan yumurtanın sağlıklı koşullarda } \\
\text { üretilip üretilmediğine güven ilişkin durumu }\end{array}$} & Evet & 239 & 61.76 \\
\hline & & Hayır & 142 & 36.69 \\
\hline & & Fikrim yok & 2 & 0.52 \\
\hline & & Cevap vermeyenler & 4 & 1.03 \\
\hline & & Toplam & 387 & 100 \\
\hline \multirow{4}{*}{7} & \multirow{4}{*}{$\begin{array}{l}\text { Yumurtanın ambalajında ya da etiketinde yer } \\
\text { alan bilgilerinin anlaşılırlık durumu }\end{array}$} & Evet & 257 & 66.41 \\
\hline & & Hayır & 127 & 32.82 \\
\hline & & Cevap vermeyenler & 3 & 0.78 \\
\hline & & Toplam & 387 & 100 \\
\hline \multirow{5}{*}{8} & \multirow{5}{*}{$\begin{array}{l}\text { Yumurta-kolesterol ilişkisi hakkında ne düşü- } \\
\text { nüldüğü durumu }\end{array}$} & Kolesterolü artırır & 65 & 16.80 \\
\hline & & Etkilemez & 186 & 48.06 \\
\hline & & Fikrim yok & 124 & 32.04 \\
\hline & & Düşürür & 12 & 3.10 \\
\hline & & Toplam & 387 & 100 \\
\hline \multirow{5}{*}{9} & \multirow{5}{*}{$\begin{array}{l}\text { Pazara sunulan kirli yumurtalar hakkında ne } \\
\text { düşünüldüğü durumu }\end{array}$} & Köy yumurtasıdır & 169 & 43.67 \\
\hline & & Organik yumurtadır & 19 & 4.91 \\
\hline & & Pazarlama stratejisidir & 197 & 50.9 \\
\hline & & Cevap vermeyenler & 2 & 0.52 \\
\hline & & Toplam & 387 & 100 \\
\hline \multirow{4}{*}{10} & \multirow{4}{*}{$\begin{array}{l}\text { Yumurtanın üzerinde yer alan kirli görünümün } \\
\text { satın alma davranışını etkileme durumu }\end{array}$} & Etkilemez & 124 & 32.04 \\
\hline & & Olumlu etkiler & 59 & 15.25 \\
\hline & & Olumsuz etkiler & 204 & 52.71 \\
\hline & & Toplam & 387 & 100 \\
\hline
\end{tabular}


Televizyon programlarında yer alan yumurtakolesterol konulu tartışmaların tüketiciler üzerinde etki yaratıp yaratmadığını belirlemek için sorulan soruya katılımcıların \% 88.86'sı herhangi bir şekilde etki yaratmadığını, \% 5.96'sı yumurta tüketimini olumsuz yönde etkilediğini, buna karşın \% 5.18'i tüketimi olumlu yönde etkilediğini belirtmişlerdir.

Yine katılımcıların yumurta-kolesterol ilişkisi hakkında yani yumurtanın kan kolesterol düzeyine etkisi hususundaki bilgi ve düşüncelerini ölçmek amaciyla sorulan soruya tüketicilerin \%47.80'i yumurtanın kan kolesterol düzeyine herhangi bir şekilde etkisinin olmayacağını, \% 32.04'ü herhangi bir fikrinin olmadığını, \% 16.80'i kan kolesterolünü artırdığını ve \% 3.10’u ise düşürdüğünü bildirmişlerdir.

$\mathrm{Bu}$ sonuçtan da anlaşılacağı üzere araştırmaya katılan tüketicilerin büyük bir kısmının yumurta kolesterolü konusunda yeterli bilince sahip olduğu belirlenmiştir. Bu çalışmanın sonucu, Güneş ve Albayrak (1997)'ın yapmış olduğu çalışmadan elde ettiği tüketicilerin kolesterol nedeniyle yumurtanın kalp-damar hastalıklarına yol açtığı kanısının daha yaygın olduğu sonucu ile çelişmektedir.

Yumurta üretimi ve satış işletmelerinin kontrol ve denetim hizmetleri Tarım ve Orman Bakanlığ tarafından yürütülmektedir. Tüketicilere ilgili kurumlar tarafından yapılan bu kontrol ve denetimleri yeterli bulup bulmadıkları konusunda fikirleri sorulmuş ve katılımcıların \%56,99'u yapılan kontrol ve denetimleri yeterli bulmadıklarını belirtmișlerdir. Tüketicilerin beklentileri bu kuruluşların kontrol ve denetimlerde daha titiz ve sorumlu davranmaları yönündedir.

$\mathrm{Bu}$ çalışmada bulunan sonuç, Mırak ve ark. (2012)'nın Türkiye genelinde yumurta tüketim bilincini ölçmek amacıyla yaptıkları çalışmada tüketicilerin \% 67.11'inin yapılan kontrol ve denetimleri yeterli bulmadığı sonucuyla paralellik göstermektedir.

Tüketicilerin \% 61.76'sının yumurtanın sağlıklı koşullarda üretildiğine inandığı ve \% 66.41'inin de yumurtanın ambalaj ve etiketlerinde yer alan tanıtıcı bilgileri anlaşılır bulduğu tespit edilmiştir. Buna karşın, bu bilgileri anlaşılır bulmayanların oranının da (\% 32.82) küçümsenmeyecek düzeyde olduğu belirlenmiştir. Bu nedenle yumurtanın ambalajında ve etiketinde bulunan bilgilerin tüketicilere tanıtılması konusunda daha duyarlı davranılmalı ve yapılacak tanıtıcı çalıșmalarla bu oran mümkün olduğunca aşağıya çekilmelidir. Doğan (2008) tarafından Adana'da yürütülen çalışmada yumurta paketleri üzerinde bulunması gereken bilgilerin Türk Gıda Kodeksi Yönetmeliği'ne uyumunun ortalama \%90 olduğu belirtilmiştir.

Tüketicilerin son yıllarda pazarlarda satılan kirli görünümlü yumurtalar hakkında ne düşündüklerini belirlemek için sorulan sorulara tüketicilerin $\%$ 50.90' bunun bir pazarlama stratejisi ve \%43.67'si de köy yumurtası olduğunu belirtmiştir. Kirli görünümlü yumurtaların tüketicilerin satın alma davranışını \%52.71 oranında olumsuz, \% 15.25 oranında ise olumlu etkilediği belirlenmiştir. Buna karşın, tüketicilerin \%32.04'ü kirli görünümlü yumurtadan olumlu ya da olumsuz etkilenmediğini bildirmiştir. Kirli görünümlü yumurtaların ne olduğu konusunda anket yapılan yörede bilinç düzeyinin düşük olduğu görülmektedir. Bu konuda tüketicilerin yeterince bilgilendirilemediği ve gerekli bilgilendirmenin yapılması gerektiği ortaya çıkmıştır.

\section{Sonuç}

Ordu ilinde ankete katılan tüketicilerin mutfağında fiyatı ne olursa olsun yumurtanın mutlaka yerini alması gereken bir ürün olarak görülmektedir. Bu nedenle de yumurta fiyatının artması ya da azalması tüketici davranışını önemli düzeyde etkilememiş ve insanlar ihtiyaçları olan yumurtayı tüketmeye devam etmişlerdir. Türk toplumunun mutfağında gelenekselleşmiş gıda maddelerinden olan ekmek gibi yumurtanın da fiyatı ne olursa olsun mutlaka sofrada yerini alması gereken bir ürün olarak görülmesinden kaynaklanmış olabileceği düşünülmektedir.

Özellikle anneler çocuklarını kahvaltıda yumurta tüketmeden okula göndermeme davranışına sahiptirler. Bu durumun araştırma alanında yumurta tüketim bilincinin yanında tüketim alışkanlığı ile de ilgili olduğu düşünülmektedir. Bu nedenle fiyat artışı ya da azalışları tüketici davranıșını önemli derecede etkilememiştir.

Yumurta etiketlerinde yer alan S, M, L, XL gibi harflerin ne anlama geldiği araştırmaya katılan tüketicilerinin önemli bir kısmı tarafından biliniyor olması tüketicilerin bu konuda yeterli bilgiye sahip olduğunun bir göstergesi olarak kabul edilebilir. Ancak, bilmeyenlerinde bu konuda bilgi sahibi olmaları için gerekli çalışmalar yapılmalıdır. Araştırmaya katılan tüketicilerin yarısı özellikle son yıllarda pazarlarda satılan yumurtaların kirli görünümlü olmasının bir pazarlama stratejisi 
olduğunu belirtirken neredeyse diğer yarısı bu yumurtaların köy yumurtası olduğunu belirtmiştir. Yine tüketicilerin önemli sayllabilecek bir kısmı kirli görünümlü yumurtaların olumlu ya da olumsuz etkilenmediğini bildirmiştir.

Kirli görünümlü yumurtaların ne olduğu ve hangi koşullarda üretildiği konusunda araștırmanın yapıldığı yöredeki tüketicilerin bilinç düzeyinin düşük ve bu konudaki düşüncelerinin net olmadığ belirlenmiştir. Bir pazarlama stratejisi olarak pazarlarda ve marketlerde kirli görünümlü olarak satılan yumurtaların hangi koşullarda nasıl üretilmiş olabilecekleri konusunda tüketicilerin bilinçlendirilmesi ve haksız kazancın önüne geçilebilmesi için gerekli çalışmalar ilgili kurum ve kuruluşlar tarafından yapılmalıdır.

Yumurtanın tüketim düzeyini daha da arttırmak için özellikle eğitim çağındaki çocuklar ve yaşlılar hedef alınarak yumurtanın yeterli ve dengeli beslenmedeki yeri ve önemi iyi bir şekilde ilgili kurum ve kuruluşlar tarafından anlatılmalıdır. Ayrıca, yumurtanın tüketimi arttırabilmek için yumurta içeren yeni ve farklı ürünler insanların tüketimine sunulmalıdır.

\section{Teșekkür}

Ordu Üniversitesi Bilimsel Araştırma Projeleri Yönetim Birimi'ne sağladıkları maddi destekten dolayı teşekkür ederiz (Proje No: BY-1709).

\section{Kaynaklar}

Akbay, C., Tiryaki, G., Gül, A., 2007. Consumer characteristics influencing fast food consumption in Turkey. Food Control, 18: 904- 913.

Akdemir, Ş., 1989. Adana ili kentsel alanda tüketicilerin yumurta alım ve tüketim davranıșları. Çukurova Üniversitesi Ziraat Fakültesi Dergisi, 4 (5): 126136.

Altan, Ö., 2015. Yumurta olușumu, kalitesi ve biyoaktif komponentleri. Ege Üniversitesi Basımevi, İzmir, 400 sayfa.

Anonim, 2017. Yumurta Üreticileri Merkez Birliği (YumBir). www.yum-bir.org/UserFiles/File/yumurtaveriler2017web.pdf Erişim tar.10.03.2018.

Çelik, Y., Şengül, T., 2001. Şanlıurfa ili kentsel alanında tüketicilerin yumurta tüketim düzeyleri ve tüketim alıșkanlıklarının belirlenmesi. Hayvansal Üretim Dergisi, 42 (2): 53-62.

Doğan, H., 2008. Adana'da Satışa Sunulan Yumurtalarda Sunuș Çeșitliliği ve Kalite Değișimi Üzerine Bir Çalıșma. Çukurova Üniversitesi Fen Bilimleri Enstitü- sü Zootekni Anabilim Dalı (Basılmamış), Yüksek Lisans Tezi, Adana, 54 sayfa.

Durmuş, İ., Demirtaş, S.E., Can, M., Kalebaşı, S., 2007. Ankara ilinde yumurta tüketim alıșkanlığının belirlenmesi. Tavukçuluk Araștırma Dergisi, 7 (1):42-45.

Erdoğan, N., 2013. Hayvansal gıdaların tüketim düzeyi ve tüketici tercihlerinin belirlenmesi üzerine bir araştırma. Afyon Kocatepe Üniversitesi Personeli Örneği. Afyon Kocatepe Üniversitesi Sosyal Bilimler Enstitüsü (Basılmamış), Yüksek Lisans Tezi (Afyonkarahisar).

Fearne, A., Lavelle, D., 1996. Segmenting the UK egg market: results of a survey of consumer attitudes and perceptions. British Food Journal, 98 (1):7-12.

Goddard, E., Boxall,P., Emunu, J.P., Boyd, C., Asselin, A., Neall, A., 2007. Consumer attitudes, willingness to pay and revealed preferences for different egg production attributes: Analysis of Canadian Egg Consumers, Project Report, Department of Rural Economy, University of Alberta, July.

Güneș, T., Albayrak, M., 1997. Türkiye tavukçuluğunda pazarlama sorunları ve çözüm önerileri. Ulusal Tavukçuluk Kongresi YUTAV Bildirileri ( İstanbul), $4: 4-14$

Hasipek, S., Aktaş, N., 1997. Türkiye'deki tavuk ürünlerinin insan beslenmesindeki önemi. Uluslararası Tavukçuluk Fuarı ve Konferansı,(14-17 Mayıs 1997, İstanbul) Bildirileri.

İskender, H., Kanbay, Y., 2014. Üniversite öğrencilerinin yumurta tüketim alıșkanlıklarının belirlenmesi. Yüzüncü Yll Üniversitesi Veterinerlik Fakültesi Dergisi, 25 (3):57-62.

Mesías, F.J., Martínez-Carrasco, F., Martínez, J.M., Gaspar, P., 2011. Functional and organic eggs as an alternative to conventional production: a conjoint analysis of consumers. Journal Science Food Agriculture, 91: 532-538.

Mızrak, C., Durmuș, İ., Kamanlı, S., Erdoğan Demirtaș, Ș., Kalebaşı, S., Karademir, E., Doğu, M., 2012. Determination of egg consumption and consumer habits in Turkey. Turkish Journal Veterinary Animimal Science, 36 (6): 592-601.

Özçiçek, D.C., 2003. Tüketicilerin işlenmiş gıda ürünlerinde kalite tercihleri, sağlık riskine karşı tutumları ve besin bileşimi konusunda bilgi düzeyleri (Adana Örneği). T.C. Tarım ve Köyișleri Bakanlığı, Tarımsal Ekonomi Araștırma Enstitüsü. Yayın No: 105, Ankara.

Özkan, K., 1986. Hayvansal besinler ve sağlık. Tarım ve Mühendislik, 18-20. 
Stadelman, W.J., Olson, V.M., Shemwell, G.A., Pasch, S., 1988. Egg and Meat Processing. Ellis Horword Ltd. Chichester (England) s.211.

Türkoğlu, M., Sarıca, S., 2014. Tavukçuluk bilimi (yetiştirme, besleme, hastalıklar). Bey Ofset Matbaacılık, Ankara, 671 sayfa.

Uluocak , A.N., Nacar, H., Cebeci, Z., Baylan, M., 1996. Bıldırcın yumurtalarında yaşla birlikte kalite özellikle- rindeki değişim. Ulusal Hayvancılık 96' Kongresi Bildiri Özeti (18-20 Eylül, İzmir), S:269-282.

Yurdakul, O., Akdemir Ş., 1989. Adana'da yumurta tüketimi ve gelir-tüketim esnekliği. Çukurova Üniversitesi Ziraat Fakültesi Dergisi, 1:1-10. 